\title{
HUBUNGAN ASUPAN ASAM LEMAK JENUH, ASAM LEMAK TIDAK JENUH DAN NATRIUM DENGAN KEJADIAN HIPERTENSI PADA WANITA MENOPAUSE DI KELURAHAN BOJONGSALAMAN
}

\author{
Lidiyawati, Apoina Kartini* ${ }^{*}$ \\ Program Studi Ilmu Gizi Fakultas Kedokteran Universitas Diponegoro \\ Jl.Dr.Sutomo No.18, Semarang, Telp (024) 8453708, Email : gizifk@undip.ac.id
}

\begin{abstract}
Background : Risk of hypertension could increase in menopausal woman, that is caused by some factors such as the lack of production of estrogen hormone and nutrients intake include sodium and fat intake. This study was objected to observe the association of saturated fatty acid, unsaturated fatty acid and sodium intake with hypertension in menopausal woman.

Method : An observasional study with case control design that involved 68 menopausal woman aged 46-60 years old $($ case $=34$, control $=34)$ in Bojongsalaman Semarang. Sampel was selected by consecutive sampling. Hypertension was detected by measurement of blood preassure using sphygmomanometer. Intake of saturated fatty acid, unsaturated fatty acid (MUFA,PUFA) and sodium were obtained by interview using semiquantitative food frequency questionaire. Bivariate anlyzed by chi-square test.

Result : Subjects in the case group had a saturated fatty acid and excess sodium intake are 94.1\% and $88.2 \%$, respectively. Most subjects in both groups have a good intake of PUFA whereas MUFA intake in the two groups was less. Results of bivariate analysis showed that SFA intake associated with hypertension $(p=0.02, O R=5,76 C I$ = 1.141-29.078), while MUFA, PUFA, sodium intake is not associated with hypertension (P>0,05).

Conclusion : Nutrient intake that associated with hypertension in menopauseal woman was saturated fatty acid, whereas unsaturated fatty acid (MUFA, PUFA) and sodium intake in this study failed to prove the associaton with hypertension.
\end{abstract}

Keyword : Hypertension; Menopause; Fatty Acid Intake; Sodium Intake

\section{ABSTRAK}

Latar belakang. : Risiko hipertensi pada wanita akan meningkat setelah mengalami menopasue yang disebabkan oleh beberapa faktor seperti penurunan produksi hormon esterogen dan asupan zat gizi termasuk asupan natrium dan juga lemak. Penelitian ini bertujuan untuk mengetahui hubungan asupan asam lemak jenuh (SFA), asam lemak tidak jenuh (MUFA,PUFA) dan natrium dengan kejadian hipertensi pada wanita menopause.

Metode : Penelitian observasional dengan desain case-control yang melibatkan 68 wanita menopause usia 46-60 tahun (kasus=34, kontrol=34) di Bojongsalaman, Semarang. Pengambilan sampel dilakukan dengan cara consecutive sampling. Kejadian hipertensi diindetifikasi dari pengukuran tekanan darah menggunakan sphygmomanometer. Asupan SFA, MUFA, PUFA, natrium diperoleh melalui wawancara dengan Food Frequency Questionaire (FFQ) semikuantitatif. Analisis bivariat menggunakan uji chi square.

Hasil : Subyek pada kelompok kasus yang memiliki asupan asam lemak jenuh dan natrium berlebih masing-masing sebesar 94,1\% dan 88,2 \%. Sebagian besar subyek pada kedua kelompok memiliki asupan PUFA yang baik sedangkan asupan MUFA pada kedua kelompok termasuk kurang. Hasil analisis bivariat menunjukkan bahwa asupan SFA berhubungan dengan kejadian hipertensi ( $p=0,02, O R=5,76, C I=1,141-29,078)$ sedangkan asupan MUFA, PUFA, natrium tidak berhubungan dengan kejadian hipertensi $(p>0,05)$.

Kesimpulan : Asupan zat gizi yang berhubungan dengan kejadian hipertensi pada wanita menopause adalah asam lemak jenuh (SFA), sedangkan asupan asam lemak tidak jenuh (MUFA, PUFA) dan natrium dalam penelitian ini tidak berhasil membuktikan adanya hubungan dengan kejadian hipertensi.

Kata Kunci : Hipertensi; Menopause; Asupan Asam Lemak; Asupan Natrium

\section{PENDAHULUAN}

Hipertensi atau tekanan darah tinggi merupakan faktor risiko penyakit kardiovaskuler yang merupakan penyebab utama kematian di dunia baik di negara maju maupun berkembang. Beberapa negara seperti Eropa dan Amerika mengemukakan bahwa angka kematian akibat penyakit kardiovaskuler lebih banyak terjadi pada wanita dibandingkan pria setiap tahunnya. ${ }^{1}$
Menurut Hasil Survei Kesehatan Rumah Tangga (SKRT) tahun 2000, prevalensi hipertensi di Indonesia diperkirakan akan meningkat menjadi $37 \%$ pada tahun 2015 dan meningkat lagi hingga $42 \%$ di tahun $2025 .^{2}$ Sedangkan berdasarkan data Dinas Kesehatan Kota Semarang terdapat 49,1\% kasus hipertensi di kota Semarang pada tahun 2012 dengan angka kejadian terbesar pada wanita dan kelompok usia 45-65 tahun. Salah satu wilayah 
dengan kasus hipertensi cukup tinggi adalah Puskesmas Karangayu yaitu 1283 kasus di tahun 2012. ${ }^{3}$

Kejadian hipertensi cenderung meningkat seiring dengan bertambahnya usia, dimana wanita memiliki risiko dua kali lebih besar setelah menopause dibandingkan wanita sebelum menopause. Peningkatan risiko tersebut disebabkan karena berkurangnya hormon esterogen pada wanita setelah mengalami menopause, sehingga menyebabkan terjadinya vasokontriksi pembuluh darah dan berakibat pada peningkatan tekanan darah. ${ }^{4}$

Selain karena adanya penurunan hormon esterogen faktor risiko lain yang dapat menyebabkan terjadinya hipertensi adalah konsumsi makanan atau diit sehari-hari. Makanan merupakan sumber asupan dari zat gizi baik makro maupun mikro. Salah satu asupan zat gizi makro dan mikro yang dianggap memiliki peranan terhadap kejadian hipertensi adalah lemak dan juga natrium. ${ }^{5}$ Menurut hasil Riset Kesehatan Dasar (Riskesdas) tahun 2007 dan 2010 sebesar 24,5\% penduduk Indonesia usia lebih dari 10 tahun mengkonsumsi makanan asin 1 kali atau lebih per hari sedangkan $12,8 \%$ penduduk Indonesia tergolong sering mengkonsumsi makanan tinggi lemak. ${ }^{6}$

Lemak terbagi menjadi asam lemak jenuh atau Saturated Fatty Acid (SFA), asam lemak tidak jenuh tunggal atau Monounsaturated Fatty Acid (MUFA) dan asam lemak tidak jenuh ganda atau Polyunsaturated Fatty Acid (PUFA). Penggolongan tersebut memiliki peranan penting terhadap kesehatan seseorang. ${ }^{7}$ Penelitian epidemiologi yang melibatkan 600 subyek di Jakarta menunjukkan bahwa asupan SFA, MUFA dan natrium merupakan faktor determinan yang mempengaruhi tekanan darah baik sistolik maupun diastolik pada subyek dengan berat badan normal. ${ }^{8}$ Menurut Hull penurunan konsumsi lemak jenuh terutama yang bersumber dari hewan dan peningkatan konsumsi lemak tak jenuh yang berasal dari biji-bijian, minyak sayur dan makanan lain yang bersumber dari tanaman dapat menurunkan tekanan darah. ${ }^{9}$ Asupan lemak jenuh/SFA yang berlebih dapat memicu terjadinya aterosklerosis yang merupakan salah satu faktor risiko hipertensi terkait dengan peningkatan resistensi dinding pembuluh darah. ${ }^{10}$ Sebaliknya asam lemak tidak jenuh baik MUFA maupun PUFA cenderung menurunkan tekanan darah terkait dengan fungsinya yang dapat menurunkan kadar kolesterol Low Density Lipoprotein (LDL). ${ }^{11}$ Menurut WHO Lemak dibutuhkan oleh tubuh sekitar 20-35\% dengan pembatasan lemak jenuh < $10 \%$, MUFA $15-20 \%$ dan PUFA $6-11 \%$ dari total energi yang dibutuhkan. ${ }^{7}$

Selain asupan lemak, asupan tinggi natrium juga berkaitan dengan terjadinya hipertensi. Hasil penelitian observasional pada wanita di Solo menunjukkan adanya hubungan positif antara asupan natrium dengan tekanan darah sistolik, namun tidak ada hubungan dengan tekanan darah diastolik $^{12}$ Asupan natrium yang berlebih dapat mengakibatkan peningkatan cairan ektraseluler yang berdampak pada meningkatnya tekanan darah. ${ }^{13}$ World Health Organization (WHO) merekomendasikan asupan natrium tidak lebih dari $2000 \mathrm{mg}$ dalam sehari (setara dengan $5 \mathrm{~g}$ garam). ${ }^{14}$

Penelitian mengenai hubungan asupan asam lemak dan natrium dengan kejadian hipertensi yang dilakukan khususnya pada wanita menopause di Indonesia masih terbatas sehingga berdasarkan uraian diatas, peneliti tertarik melakukan penelitian yang bertujuan untuk mengetahui hubungan asupan asam lemak jenuh, asam lemak tidak jenuh dan natrium dengan kejadian hipertensi pada wanita menopause. Hasil penelitian ini diharapkan dapat memberikan informasi pada masyarakat khususnya wanita menopause mengenai faktor yang berhubungan dengan hipertensi terutama dari segi asupan makanan dan zat gizi.

\section{METODE PENELITIAN}

Penelitian ini termasuk dalam ruang lingkup keilmuan gizi masyarakat dan merupakan penelitian analitik observasional dengan rancangan case control study. Penelitian dilakukan pada bulan Mei-Juni 2014 di salah satu wilayah kerja Puskesmas Karangayu kota Semarang yaitu di kelurahan Bojongsalaman.

Besar sampel minimal dihitung menggunakan rumus dan didapatkan sampel sebanyak 66 yang terdiri dari 33 kelompok kasus dan 33 kelompok kontrol. Jumlah sampel yang didapatkan dalam penelitian adalah 34 subyek untuk masing-masing kelompok dengan metode consecutive sampling. kriteria inklusi adalah wanita menopause usia 46-60 tahun, memiliki tekanan darah sistolik $\geq 140 \mathrm{mmHg}$ dan atau tekanan darah diastolik $\geq 90 \mathrm{mmHg}$ untuk kelompok kasus, memiliki tekanan darah normal (tekanan darah sistolik antara 110-120mmHg dan atau tekanan darah diastolik $70-80 \mathrm{mmHg}$ ) untuk kelompok kontrol, tidak sedang mengkonsumsi obat yang dapat menurunkan tekanan darah, dan bersedia mengisi formulir informed consent.

Variabel terikat dalam penelitian ini adalah hipertensi pada wanita menopause sedangkan 
variabel bebas adalah asupan asam lemak jenuh (SFA), asam lemak tidak jenuh (MUFA, PUFA) dan natrium. Data yang dikumpulkan meliputi data umum subyek, data tekanan darah, data antropometri, data aktivitas fisik dan data asupan makanan subyek.

Data tekanan darah diperoleh melalui pemeriksaan yang dilakukan oleh tenaga kesehatan (perawat). Cara pengukuran tekanan darah yaitu dengan duduk dikursi dan diawali dengan mengistirahatkan subyek selama 5 menit kemudian memeriksa tekanan darah menggunakan sphygmomanometer air raksa dan stetoskop. Pengukuran dilakukan sebanyak 2 kali. ${ }^{15}$ Subyek termasuk hipertensi jika tekanan darah sistolik $\geq 140 \mathrm{mmHg}$ dan atau tekanan diastolik $\geq 90$ mmHg. ${ }^{16}$ Data antropometri didapat dari hasil pengukuran berat badan menggunakan timbangan digital dengan ketelitian $0,1 \mathrm{~kg}$ dan pengukuran tinggi badan menggunakan mikrotoise dengan ketelitian $0,1 \mathrm{~cm}$. Pengukuran antropometri dilakukan untuk menentukan Indeks Massa Tubuh (IMT) subyek penelitian. Dikatakan Obesitas apabila IMT $\geq 25 \mathrm{~kg} / \mathrm{m}^{2}$ dan tidak obesitas apabila IMT $<25 \mathrm{~kg} / \mathrm{m}^{2} .{ }^{17}$

Data aktvitas fisik diperoleh secara langsung menggunakan formulir IPAQ (Internasional Physical Activity Questionnare). Aktivitas fisik merupakan kegiatan fisik yang dilakukan sehari-hari selama 7 hari dinyatakan dalam satuan MET.menit/minggu. Aktivitas fisik dikatakan rendah apabila <600 MET.menit/minggu dan normal apabila $\geq 600$ MET.menit/minggu. ${ }^{18}$

Data asupan makanan subyek diperoleh secara langsung menggunakan FFQ (Food Frequency Questionaire) semi kuantitatif. Asupan asam lemak jenuh (SFA) dan asam lemak tidak jenuh (MUFA, PUFA) merupakan rata-rata gram/hari asupan asam lemak jenuh (SFA), asam lemak tidak jenuh (MUFA, PUFA) yang bersumber dari makanan atau minuman. Asupan asam lemak jenuh dikatakan baik apabila asupan $<10 \%$ dan lebih apabila $\geq 10 \%$ dari total kebutuhan energi masing-masing subyek penelitian. Asupan asam lemak tidak jenuh MUFA dikatakan kurang apabila asupan $<15 \%$ dan baik apabila $\geq 15 \%$ dari total kebutuhan energi masing-masing subyek penelitian. Sedangkan asupan asam lemak tidak jenuh PUFA dikatakan kurang jika asupan <6\% dan baik apabila $\geq 6 \%$ dari total kebutuhan energi masing-masing subyek subyek penelitian.,19 Asupan natrium merupakan rata-rata $\mathrm{mg} / \mathrm{hari}$ asupan natrium yang bersumber dari makanan atau minuman. Asupan natrium dikatakan lebih apabila $>100 \%$ dan baik apabila mencapai $80-100 \%$ dari total kebutuhan dalam sehari. ${ }^{20}$

Pengolahan dan analisis data menggunakan program Nutrisurvey 2005 dan Statistical Package For The Social Science (SPSS) 16 for windows. Analisis univariat digunakan untuk menggambarkan karakteristik subyek penelitian. Analisis bivariat digunakan untuk mengetahui hubungan asupan SFA, MUFA, PUFA dan natrium dengan hipertensi menggunakan uji chi-square namun jika pada tabel memiliki expected value kurang dari 5 lebih dari $20 \%$ digunakan uji Fisher Exact. Besar risiko dihitung dengan nilai odd rasio (OR). ${ }^{21}$

\section{HASIL PENELITIAN \\ Karakteristik Subyek}

Dari hasil skrining yang melibatkan 236 wanita menopause usia 46-60 tahun ditemukan 63 wanita yang menderita hipertensi (26,7\%). Namun, berdasarkan kriteria inklusi hanya 34 wanita hipertensi yang memenuhi syarat untuk menjadi subyek penelitian sehingga total keseluruhan sampel yang didapat dalam penelitian adalah 68 yang terdiri dari 34 kelompok kasus (hipertensi) dan 34 kelompok kontrol (tidak hipertensi). Data karakteristik subyek penelitian ditampilkan pada tabel 1, sedangkan data nilai rerata, standar deviasi, nilai minimal dan maksimal tekanan darah, usia, IMT, aktivitas fisik, asupan SFA, MUFA, PUFA dan natrium ditunjukkan dalam tabel 2.

Tabel 1. Karakteristik Subyek Berdasarkan Usia, Pekerjaan, Pendidikan, Riwayat Hipertensi, IMT dan Aktivitas Fisik

\begin{tabular}{lccccc}
\hline Variabel & \multicolumn{2}{c}{ Kasus } & \multicolumn{2}{c}{ Kontrol } & \multirow{2}{*}{$\mathrm{P}$} \\
\cline { 2 - 5 } & $\mathrm{n}$ & $\%$ & $\mathrm{n}$ & $\%$ & \\
\hline Usia & & & & & \multirow{2}{*}{0,22} \\
$46-55$ & 13 & 38,2 & 18 & 52,9 & \\
$\geq 56$ & 21 & 61,8 & 16 & 47,1 & \\
\hline Total & 34 & 100 & 34 & 100 & 0,45 \\
\hline Pendidikan & 19 & 55,9 & 22 & 64,7 & \\
Pendidikan Dasar & 15 & 44,1 & 12 & 35,3 & \\
Pendidikan Lanjut & 34 & 100 & 34 & 100 & \\
\hline Total & & & & & \\
\hline
\end{tabular}




\begin{tabular}{lccccc}
\hline Pekerjaan & & & & & \\
Tidak Bekerja & 27 & 79,4 & 24 & 70,6 & 0,40 \\
Bekerja & 7 & 20,6 & 10 & 29,4 & \\
\hline Total & 34 & 100 & 34 & 100 & \\
\hline Riwayat Hipertensi & & & & & \\
Ya & 10 & 29.4 & 8 & 23.5 & 0,58 \\
Tidak & 24 & 70.6 & 26 & 76.5 & \\
\hline total & 34 & 100 & 34 & 100 & \\
\hline IMT & & & & & \\
Obesitas $\left(\geq 25 \mathrm{~kg} / \mathrm{m}^{2}\right)$ & 22 & 64,7 & 15 & 44,1 & 0,08 \\
Tidak Obesitas $\left(<25 \mathrm{~kg} / \mathrm{m}^{2}\right)$ & 12 & 35,3 & 19 & 55,9 & \\
\hline Total & 34 & 100 & 34 & 100 & \\
\hline Aktivitas fisik $(\mathrm{MET} . \mathrm{menit} / \mathrm{mgu})$ & & & & & \\
Rendah $<600$ & 8 & 23,5 & 7 & 20,6 & 0,77 \\
Normal $\geq 600$ & 26 & 76,5 & 27 & 79,4 & \\
\hline Total & 34 & 100 & 34 & 100 & \\
*uji chi-square & & & & &
\end{tabular}

Berdasarkan tabel 1 diketahui bahwa tidak terdapat perbedaan kararkteristik usia, pendidikan, pekerjaan, riwayat hipertensi, IMT dan aktivitas

fisik subyek pada kelompok kasus maupun kontrol $(\mathrm{p}>0,05)$.

Tabel 2. Nilai rerata, standar deviasi, minimal dan maksimal tekanan darah, Usia, IMT, Aktifitas fisik, asupan SFA, MUFA, PUFA, Natrium pada kelompok kasus dan kontrol

\begin{tabular}{lcccccc}
\hline \multirow{2}{*}{ Variabel } & \multicolumn{3}{c}{ Kasus } & \multicolumn{3}{c}{ Kontrol } \\
\cline { 2 - 7 } & Mean \pm SD & Minimal & Maksimal & Mean \pm SD & Minimal & Maksimal \\
\hline Tekanan Darah & & & & & & \\
$\quad$ Sistolik & $141,91 \pm 10,37$ & 120 & 155 & $115,44 \pm 4,15$ & 110 & 120 \\
\multicolumn{1}{c}{ Diastolik } & $90,00 \pm 3,48$ & 80 & 95 & $73,82 \pm 4,09$ & 70 & 80 \\
\hline Usia & $55,79 \pm 4,11$ & 46 & 60 & $55,18 \pm 4,50$ & 46 & 60 \\
\hline IMT & $26,76 \pm 5,03$ & 18,6 & 41,3 & $24,34 \pm 2,98$ & 18,9 & 30 \\
\hline Aktivitas Fisik & $989,39 \pm 491,59$ & 411,0 & 3306,0 & $1090 \pm 635,20$ & 466,5 & 3346,0 \\
\hline Asupan & & & & & & \\
SFA (g) & $24,30 \pm 3,55$ & 17,3 & 34,5 & $20,32 \pm 2,93$ & 15,0 & 27,0 \\
MUFA (g) & $14,13 \pm 3,44$ & 9,1 & 24,9 & $13,30 \pm 4,30$ & 6,5 & 26,8 \\
PUFA (g) & $15,28 \pm 5,33$ & 6,1 & 25,2 & $16,76 \pm 5,48$ & 6,2 & 25,5 \\
Natrium (mg) & $2356 \pm 241,38$ & 1929,3 & 2861,3 & $2222 \pm 173,74$ & 1928,8 & 2568,2
\end{tabular}

Catata $=$ SFA $=$ saturated fatty acid $/$ asam lemak jenuh, MUFA $=$ monounsaturated fatty acid $/$ asam lemak tidak jenuh tunggal, PUFA = polyunsaturated fatty acid/ asam lemak tidak jenuh ganda, IMT= Indeks Massa Tubuh

Pada tabel 2 ditunjukkan bahwa nilai rerata usia subyek pada kelompok kasus adalah $(55,79 \pm 4,11)$ dan pada kelompok kontrol adalah $(55,18 \pm 4,50)$. Sedangkan nilai rerata tekanan darah sistolik $(141,91 \pm 10,37)$ dan diastolik $(90,00 \pm 3,48)$ pada kelompok kasus lebih tinggi dibanding dengan kelompok kontrol. Begitu juga dengan nilai rerata IMT pada kelompok kasus yang lebih tinggi $(26,76 \pm 5,03)$ dibanding kelompok kontrol.

Berdasarkan tabel 2 juga diketahui bahwa subyek pada kelompok kasus memilki nilai rerata asupan asam lemak jenuh, asam lemak tidak jenuh tunggal dan natrium yang lebih tinggi dibanding dengan kelompok kontrol. Sementara itu, nilai rerata aktivitas fisik dan asupan asam lemak tidak jenuh ganda pada kelompok kasus lebih rendah dibanding kelompok kontrol.

Hubungan Asupan Asam Lemak Jenuh (SFA), Asam Lemak Tidak Jenuh (MUFA, PUFA) dan Natrium dengan Kejadian Hipertensi 
Tabel 3. Analisis Bivariat

\begin{tabular}{|c|c|c|c|c|c|c|c|}
\hline \multirow[t]{2}{*}{ Asupan } & \multicolumn{2}{|c|}{ kasus } & \multicolumn{2}{|c|}{ kontrol } & \multirow[t]{2}{*}{$\mathrm{p}$} & \multirow[t]{2}{*}{ OR } & \multirow[t]{2}{*}{$95 \% \mathrm{CI}$} \\
\hline & $\mathrm{n}$ & $\%$ & $\mathrm{n}$ & $\%$ & & & \\
\hline \multicolumn{8}{|l|}{ SFA } \\
\hline Lebih & 32 & 94,1 & 25 & 73,5 & $0,02^{c}$ & $5,76^{\mathrm{a}}$ & $1,141-29,078$ \\
\hline Baik & 2 & 5,9 & 9 & 26,5 & & & \\
\hline \multicolumn{8}{|l|}{ MUFA } \\
\hline Kurang & 33 & 97,1 & 31 & 91,2 & 0,61 & $3,19^{b}$ & $0,315-32,356$ \\
\hline Baik & 1 & 2,9 & 3 & 8,8 & & & \\
\hline \multicolumn{8}{|l|}{ PUFA } \\
\hline Kurang & 4 & 11,8 & 1 & 2,9 & 0,35 & $4,40^{\mathrm{b}}$ & $0,465-41,596$ \\
\hline Baik & 30 & 88,2 & 33 & 97,1 & & & \\
\hline \multicolumn{8}{|l|}{ Natrium } \\
\hline Lebih & 30 & 88,2 & 26 & 76,5 & 0,20 & $2,30^{\mathrm{a}}$ & $0,623-8,554$ \\
\hline Baik & 4 & 11,8 & 8 & 23,5 & & & \\
\hline
\end{tabular}

Tabel 3 menunjukkan persentase subyek yang mengkonsumsi asam lemak jenuh berlebih $(94,1 \%)$ dan natrium berlebih $(88,2 \%)$ lebih tinggi pada kelompok kasus dibanding dengan kelompok kontrol, sedangkan untuk asupan asam lemak tidak jenuh ganda pada sebagian besar subyek baik kelompok kasus $(88,2 \%)$ maupun kontrol $(97,1 \%)$ termasuk dalam kategori baik. Sebaliknya, asupan asam lemak tidak jenuh tunggal pada kedua kelompok termasuk dalam kategori kurang.

Berdasarkan hasil analisis bivariat pada tabel 3 menunjukkan bahwa asupan asam lemak jenuh memiliki hubungan yang bermakna dan merupakan faktor risiko hipertensi pada wanita menopause $(\mathrm{P}=0,02, \mathrm{OR}=5,76$, CI $95 \%=1,141$ 29,078), sedangkan asupan asam lemak tidak jenuh MUFA, PUFA dan natrium tidak berhubungan dengan kejadian hipertensi karena nilai $\mathrm{P}>0,05$.

\section{PEMBAHASAN}

Berdasarkan hasil penelitian ini diketahui prevalensi hipertensi pada wanita menopause usia 46 - 60 tahun sebesar 26,7\%, dimana lebih dari separuh subyek pada kelompok kasus $(61,8 \%)$ memiliki usia 56 tahun atau lebih. Kejadian hipertensi akan meningkat seiring dengan bertambahnya usia yang mana pada wanita akan meningkat terutama setelah mengalami menopause. Wanita menopause berisiko dua kali lebih besar mengalami hipertensi terkait dengan menurunnya hormon esterogen yang dapat berfungsi sebagai vasodilator. ${ }^{4}$ Pada penelitian ini juga menunjukkan bahwa sebesar $64,7 \%$ subyek yang menderita hipertensi memiliki IMT dalam kategori obesitas, hal ini kemungkinan dikaitkan dengan adanya peningkatan aktivasi sistem saraf simpatis dan RAA (Renin-AngiotensinAldosteron) yang berlebihan pada orang obesitas sehingga meningkatkan risiko peningkatan tekanan darah. ${ }^{22}$ Selain itu, asupan zat gizi juga dapat berpengaruh terhadap kejadian hipertensi salah satunya adalah asupan asam lemak dan juga natrium. $^{5}$

Dalam penelitian ini diketahui bahwa sebesar $94,1 \%$ wanita menopause yang menderita hipertensi memiliki asupan asam lemak jenuh berlebih. Sumber lemak jenuh yang paling banyak dikonsumsi oleh subyek dalam penelitian adalah minyak kelapa, santan, dan lauk hewani seperti daging ayam dengan kulit. Asupan asam lemak jenuh yang berlebih dapat menyebabkan terjadinya dislipidemia yang merupakan faktor risiko aterosklerosis. ${ }^{23}$ Aterokslerosis dapat memicu terjadinya hipertensi. Hal ini disebabkan karena pembuluh darah yang mengalami aterosklerosis selain terjadi peningkatan resistensi pada dindingnya juga mengalami penyempitan, sehingga memicu peningkatan denyut jantung dan peningkatan volume aliran darah yang berakibat pada meningkatnya tekanan darah serta terjadi hipertensi. ${ }^{10}$ Teori tersebut mendukung hasil penelitian ini yang menunjukkan bahwa asupan asam lemak jenuh berhubungan dengan kejadian hipertensi $(p=0,02)$, dimana wanita menopause yang mempunyai asupan lemak jenuh berlebih berisiko 5,76 kali lebih besar untuk menderita hipertensi dibandingkan wanita menopause yang mempunyai asupan asam lemak jenuh baik. Hasil ini sesuai dengan penelitian yang dilakukan oleh Syukraini yang menyebutkan bahwa risiko untuk menderita hipertensi pada orang yang mengkonsumsi lemak terutama lemak jenuh dalam jumlah tinggi adalah 8,7 kali lebih besar dibanding dengan orang yang mengkonsumsi lemak jenuh dalam jumlah rendah. ${ }^{24}$

Hasil penelitian untuk tingkat kecukupan asupan asam lemak tidak jenuh baik MUFA maupun PUFA pada kedua kelompok tidak 
menujukkan adanya perbedaan. Sumber makanan yang tinggi akan kandungan asam lemak tak jenuh tunggal adalah minyak zaitun, kacang almond dan juga lemak yang terdapat pada alpukat. ${ }^{25}$ Namun, berdasarkan hasil wawancara langsung dengan subyek selama penelitian diketahui bahwa hampir sebagian besar subyek pada kedua kelompok justru tidak pernah mengkonsumsi sumber minyak yang berasal dari tumbuh-tumbuhan karena harganya yang tidak terjangkau sehingga menyebabkan konsumsi asam lemak tak jenuh tunggal pada sebagian besar subyek baik pada kelompok yang menderita hipertensi maupun tidak, termasuk dalam kategori kurang. Sementara untuk asupan PUFA hanya sedikit dari subyek baik kelompok kasus (11,8\%) maupun kontrol (2,9\%) yang memiliki asupan kurang. Hampir sebagian besar dari mereka memiliki kebiasaan mengkonsumsi ikan, kacang tanah, tempe dan tahu yang merupakan sumber asam lemak tak jenuh ganda.

Mekanisme pasti mengenai hubungan asupan asam lemak tak jenuh baik MUFA maupun PUFA dengan kejadian hipertensi masih belum sepenuhnya dapat dipahami. Asupan tinggi asam lemak tidak jenuh MUFA maupun PUFA memiliki pengaruh dalam penurunan kadar kolesterol LDL sehingga dapat memperkecil risiko peningkatan tekanan darah oleh adanya penumpukan kolesterol. ${ }^{26,27}$ Selain itu, asupan asam lemak tak jenuh ganda yang terdiri dari omega3 dan omega 6 dapat meningkatkan produksi prostaglandin yang berperan sebagai vasodilator. $^{28}$ Meskipun demikian, hasil penelitian ini secara statistik tidak menunjukkan adanya hubungan yang bermakna antara asupan MUFA maupun PUFA dengan kejadian hipertensi $(p>0,05)$, sehingga penelitian ini tidak berhasil membuktikan hipotesis yang ada. Kemungkinan hal ini terkait dengan cara pengolahan dalam mengkonsumsi sumber makanan asam lemak tidak jenuh yang mana sebagian besar dari subyek mengkonsumsi dengan cara di goreng. Adanya proses penggorengan menyebabkan penyerapan lemak atau minyak kedalam bahan makanan sehingga dapat terjadi modifikasi terhadap komposisi maupun kandungan zat gizi bahan makanan tersebut. Perubahan yang dihasilkan bergantung pada komposisi lemak yang digoreng dan yang terkandung dalam bahan makanan serta kondisi penggorengan seperti lamanya waktu atau durasi serta suhu yang digunakan. ${ }^{29}$

Dari hasil penelitian untuk tingkat kecukupan asupan natrium diketahui bahwa sebanyak $30(88,2 \%)$ wanita menopause yang menderita hipertensi memiliki asupan natrium berlebih. Sumber natrium yang paling banyak dikonsumsi oleh subyek dalam penelitian adalah garam, monosodium glutamat, ikan asin dan kecap. Natrium merupakan kation utama dalam cairan ektraseluler yang berperan penting dalam mempertahankan volume plasma dan ektraseluler, keseimbangan asam-basa dan juga fungsi neuromuskular. ${ }^{30}$ Asupan tinggi natrium dapat menyebabkan konsentrasi natrium di dalam cairan ekstraseluler meningkat sehingga untuk menormalkannya cairan intraseluler ditarik keluar dan mengakibatkan peningkatan cairan ektraseluler yang mengakibatkan meningkatnya volume darah dan berdampak pada peningkatan tekanan darah. ${ }^{13}$ Meskipun demikian, hasil penelitian ini menunjukkan bahwa secara statistik asupan natrium tidak berhubungan dengan kejadian hipertensi $(p>0,05)$, sehingga penelitian ini tidak berhasil membuktikan hipotesis yang ada. Hal ini kemungkinan disebabkan karena reaksi individu terhadap jumlah natrium didalam tubuh berbeda tergantung pada sensitivitas yang dimiliki oleh individu tersebut. Adanya asupan zat gizi lain seperti kalium juga dapat mempengaruhi respon natrium terhadap tekanan darah. Kalium merupakan kation utama dalam cairan intraseluler yang memiliki fungsi sama seperti natrium. Asupan tinggi kalium dapat meminimalisir peningkatan tekanan darah oleh adanya natrium yang berlebih. ${ }^{31}$ Terdapat penelitian yang menyebutkan bahwa rasio natrium dan kalium dalam urin lebih kuat untuk menggambarkan hubungannya dengan tekanan darah. ${ }^{32}$ Sedangkan dalam penelitian ini hanya dilakukan analisis pada asupan natrium yang bersumber dari makanan atau minuman tanpa menganalisis rasio natrium dan kalium pada urin.

\section{SIMPULAN}

Asupan asam lemak jenuh $\geq 10 \%$ dari total energi yang dibutuhkan berhubungan dengan kejadian hipertensi pada wanita menopause sedangkan asupan asam lemak tidak jenuh tunggal, asam lemak tidak jenuh ganda dan natrium dalam penelitian ini tidak berhasil membuktikan adanya hubungan dengan kejadian hipertensi.

\section{SARAN}

Perlu adanya sosialisasi pada masyarakat khususnya wanita menopause mengenai pentingnya menjaga pola makan terutama dalam pembatasan asupan lemak jenuh yang banyak terdapat pada bahan makanan seperti minyak kelapa, santan, lauk hewani maupun makanan yang digoreng dan asupan natrium terutama dalam 
penggunaan garam dan Monosodium glutamate (MSG).

\section{DAFTAR PUSTAKA}

1. Cifkova R, Pithab J, Lejskovac M, Lanskad V, Zecova S. Blood Pressure Around The Menopause: A Population Study. Journal of Hypertension 2008, 26:1976-1982

2. Badan Litbangkes Depkes RI. Laporan Survei Kesehatan Rumah Tangga (SKRT). Jakarta: Litbangkes; [Serial Online ] 2011 [cited 2014 March 12]. Available from: http://www.jatlitbangkers.or.id

3. Dinas Kesehatan kota Semarang. Rekap Prevalensi PTM Kota Semarang Tahun 2012. Semarang. 2012

4. Barton M, Meyer MR. Postmenopausal Hypertension: Mechanisms and Therapy. Journal of American Heart Assosiation. 2009;54:11-18

5. Appel LJ, Brands MW, Daniels SR, et al. Dietary Approaches to Prevent and Treat Hypertension: A Scientific Statement From the American Heart Association. Journal of American Heart Assosiation. 2006;47:296-308

6. Tjandra, YA. Informasi Terkait PTM. [Serial Online] 2013 [cited 2014 March 17] available from: htttp://www.pppl.depkes.go.id

7. World Health Organization. Interim Sumary Of Conclusion And Dietary Recomendation On Total Fat \& Fatty Acid. Geneva : WHO, 2008

8. Kamso J, Johanna S.P, Rumawas, Lukito W, Purwantyastuti. Determinants Of Blood Pressure Among Indonesian Elderly Individuals Who Are Of Normal And Over-Weight: A Cross Sectional Study In An Urban Population. Asia pacific Journal Clinical Nutrition. 2007;16 (3):546-553

9. Hull-alison. Penyakit Jantung, Hipertensi, Dan Nutrisi. Jakarta : Bumi Aksara: 1996. Hal.1-31

10. Anwar TB. Dislipidemia Sebagai Faktor Resiko Penyakit Jantung Koroner. Medan : Fakultas Kedokteran universitas Sumatra utara; 2004

11. Agustini Z, Wahyuni ES, Nila F. Hubungan Asupan Lemak (Lemak Jenuh, Tak Jenuh, Kolesterol) Dan Natrium Terhadap Tekanan Darah Pada Pasien Hipertensi Di Poli Penyakit Dalam Rsp Batu [Skripsi]. Program Studi Ilmu Gizi Fakultas Kedokteran Universitas Brawijaya Malang; 2013

12. Sase FA, Pramono A. Hubungan Durasi Aktivitas Fisik Dan Asupan Natrium Dengan Tekanan Darah Pada Wanita Menopause. Journal Of Nutrition College, volume 2, nomor 2, tahun 2013, halaman 287-293

13. Astawan Made. Cegah Hipertensi dengan Pola Makan, [Serial Online] 2007, [cited 2014 March 10] available from: htttp://www.depkes.go.id.

14. World Health Organization. Guidline : Sodium Intake For Adults And Children. Geneva: WHO, 2012
15. British Hypertension Society. Guidelines For Management Of Hypertension: Report Of The Fourth Working Party For The British Hypertension Society. J Hum Hypertension. 2004; 18:139-85

16. Martin J. Hypertension Guidelines: Revisiting The JNC 7 Recommendation. The Journal of Lancaster General Hospital. Vol. 3 No. 3. 2008

17. Wold Health Organisation Western Pasific Region. The Asia Pasific Perspective: Redefining Obesity And Its Treatment. Australia: 2000

18. International Physical Activity Questionnaire. Guidelines for data processing and analysis of the International Physical Activity Questionnaire (IPAQ). Short and Long Form. Revised November 2005. Available from: www.ipaq.ki.se

19. Raylene M. Rospond. 2008. Penilaian Status Nutrisi. [cited 2014 April 7] available from: htttp://lyrawati.files.wordpress.com/2008/07/penila ian-statusnutrisi.pdf

20. Widajati L. 2009. Survei Konsumsi Gizi. Fakultas Kesehatan Masyrarakat Universitas Diponegoro

21. Dahlan S. Statistik untuk Kedokteran dan Kesehatan. Jakarta: Salemba Medika;2011

22. Amira C.O, Sokunbi D.O.B, Sokunbi A. The Prevalence Of Obesity And Its Relationship With Hypertension In An Urban Community: Data From World Kidney Day Screening Programme. International Journal Of Medical And Biomedical Research Vol 1 Issue 2 May- August 2012

23. Manurung E. Hubungan Antara Asupan asam lemak Tak Jenuh Tunggal dengan Kadar Kolesterol HDL Plasma Penderita Penyakit Jantung Koroner. [Tesis]. Program Magister Sains Ilmu Gizi Klinik Universitas Indonesia, Jakarta;2004

24. Irza S. Analisis Faktor Hipertensi Pada Masyarakat Nagara Bungo Tanjung Sumatera Barat [Skripsi]. Fakultas Farmasi Universitas Sumatera Utara Medan; 2009

25. United States Departement Of Agriculture, Agricultural Research Service. USDA National Data Base For Standard Reference Release 26. [online] [cited 2 apr 2014] available from: www. ndb.na.usda.gov

26. Murray RK, Daryl KG, Victor WR. 2009. Biokimia Harper. Edisi 27. Jakarta: EGC

27. Rahardja E.M. 2004. Faktor Gizi Dalam Regulasi Tekanan Darah. Ebers Papyrus volume 10 nomor 3.

28. Couch SC, Krummel DA. Medical Nutrition Therapy for Hypertension. In: Mahan LK, EscottStump S,editors. Krause's Food and Nutrition Therapy.12 th ed. USA: Saunders; 2008. p 865878

29. Soerjodibroto W. Lemak Dalam Pola Makanan Masyarakat Indonesia Dan Masyarakat Kawasan Asia Pasifik Lainnya [Tesis]. Fakultas Kedokteran Universitas Indonesia Jakarta; 2005 
30. Ghidurus M, Turtor M, Boskou G, Niculita P, Stan V. Nutrional and Health Aspects Related to Frying. Romanian Biotechnological University of Bucharest. 2010; Vol.15,No.6

31. Appel LJ. Diet And Blood Pressure. Nutrition Diet and Hypertension In: Rous AC, Caballero B, Cousins RJ, Tucker KL, Ziegler TR. Modern Nutrition And Health Disease. 11th ed. Philadelpia: Wolters Kluwer; 2011. P 875-886

32. Theodore AK, Jane MK. Nutrition Diet and Hypertension. Hypertension In: Rous AC, Caballero B, Cousins RJ, Tucker KL, Ziegler TR. Modern Nutrition And Health Disease.10 th ed. Philadelpia: Wolters Kluwer ; 2006. P 1095-1102 